УДК 636.2.034, DOI 10.31210/visnyk2018.02.16

(C) 2018

Скляренко Ю. І., кандидат сільськогосподарських наук

Інститут сільського господарства Північного Сходу НААН

\title{
ЕФЕКТИВНІСТЬ ДОВІЧНОГО ВИКОРИСТАННЯ КОРІВ ЗАЛЕЖНО ВІД ГЕНОТИПОВИХ ФАКТОРІВ
}

\section{Рецензент - кандидат сільськогосподарських наук О. М. Бордун}

У статті висвітлено основні результати досліджень щзодо визначення впливу генотипових факторів на показники довічного використання корів. Встановлено, шо дочки за всіма показниками довічного використання поступаються своӥм матерям. Розраховані в ході досліджень величини коефічієнтів успадкування («дочка - мати») та сили впливу на показники довічного використання корів за методом «батько - дочка» в умовах великомасштабної селекиії молочної худоби дають підстави очікувати вищої ефективності підбору з інтенсивним використанням бугаїв-поліпшувачів за ознаками довічного використання корів у порівнянні з методом «мати - дочка». Сила впливу походження за батьком на показники довічного використання становить 20,5-33,4\%.

Ключові слова: бугай-плідник, родина, довічна продуктивність, коефіцієнт, лактація, надій.

Постановка проблеми. Вітчизняні вчені стверджують, що тривале господарське використання високопродуктивних тварин є беззаперечною передумовою та найважливішим чинником ефективного довічного використання молочної худоби, забезпечення високої рентабельності та конкурентоспроможності галузі в умовах формування ринкових відносин [4].

Селекційна робота в молочному скотарстві, направлена на цілеспрямоване використання тварин, здатних покращувати продуктивність, тип будови тіла, екстер'єрні ознаки і підвищувати продуктивне довголіття. Тривалість продуктивного використання тварин є однією із важливих селекційних ознак. Корови, які мало використовуються в господарстві, як правило, збиткові навіть за високої молочної продуктивності. Продуктивне довголіття тварин генетично детерміноване, а його мінливість зумовлена реакцією генотипу на умови зовнішнього середовища [7].

Аналіз останніх досліджень i публікацій, у яких започатковано розв'язання проблеми. Результати досліджень вітчизняних науковців свідчать про те, що тривалість використання та довічна продуктивність корів української чорнорябої молочної породи детермінується індивідуальною спадковістю бугаїв-плідників. Потомство бугаїв вітчизняної селекції виявилося кращим за показниками продуктивного довголіття, ніж потомки чистопородних голштинських плідників [1].

Дослідники стверджують, що кращими за показниками тривалості життя, господарського використання, числом лактацій за життя та довічної продуктивності у стаді корів української червоно-рябої молочної породи виявилися помісні генотипи 3 умовною кровністю голштинської породи 50,1-62,5 \%. Із нарощуванням кровності голштина продуктивність помісних корів за лактацію зростала, проте істотно знижувалися показники довголіття та довічної продуктивності, особливо у висококровних тварин зі спадковістю поліпшуючої породи вище за 75,1% [9, 10].

У зв’ язку з відсутністю бугаїв-плідників власної селекції, важливим питанням $є$ правильний вибір іноземних бугаїв-плідників. Науковцями встановлено, що дочки бугаїв-плідників різних країн селекції відрізнялися між собою за показниками тривалості та ефективності їх довічного використання. Серед тварин голштинської породи кращими за тривалістю життя, продуктивного використання, лактування, кількістю лактацій за життя та довічною продуктивністю виявилися корови, які походили від бугаїв угорської та канадської селекції, 3-поміж тварин української чорно-рябої молочної породи - корови, одержані від плідників російської та української селекції, а серед тварин української червоно-рябої молочної породи - дочки канадських та вітчизняних бугаїв. Сила впливу батька на продуктивне довголіття тварин була суттєвішою, ніж сила впливу країни походження бугаїв-плідників [1].

Автори стверджують, що показники тривалості та ефективності довічного використання корів залежать від їх походження за батьком, лінії батька, лінії матері та різних варіантів підбору батьків. Більший вплив на досліджувані показники тривалості та ефективності довічного використання тварин справляло походження за батьком $(51,6-55,2 \%)$, значно менший - лінія батька (16,5-19,0 \%) та лінія матері (10,3-11,4\%) [2].

Мета досліджень - вивчити залежність показників прижиттєвої продуктивності та тривалос- 


\section{СІЛЬСЬКЕ ГОСПОДАРСТВО. ТВАРИННИЦТВО}

ті господарського використання корів від генетичних чинників.

Завдання досліджень - виявити зміни показників прижиттєвої продуктивності та тривалості господарського використання корів у поколіннях, встановити на них силу впливу генотипових факторів.

Матеріал і методи досліджень. Дослідження проведено за матеріалами первинного племінного обліку в стаді одного з провідних племінних заводів 3 розведення української бурої молочної породи великої рогатої худоби ДП ДГ ІСГПС НААН Сумської області. Використано матеріали електронної інформаційної бази даних у форматі СУМС ОРСЕК станом на 2017 рік $(\mathrm{n}=62)$.

Iз показників тривалості та ефективності довічного використання корів визначали тривалість (днів) життя (Тж), тривалість господарського використання (Тгв) і тривалість лактування (Тдл), число лактацій за життя, довічний надій (кг), середній довічний вміст (\%) жиру в молоці, надій (кг) на один день життя, господарського використання і лактування. Коефіцієнт господарського використання (Кгв) обчислювали (для зручності - 3 вираженням у відсотках) за пропонованою М. С. Пелехатим зі співавторами. Крім того визначали (так само у відсотках) пропоновані Полупаном Ю. П. коефіцієнт лактування (Кл) i коефіцієнт продуктивного використання (Кпв) [10].

Статистичну обробку результатів досліджень проводили методами математичної статистики за допомогою ПЕОМ [3, 6].

Результати досліджень. У результаті проведених досліджень нами встановлено, що у тварин української бурої молочної породи погіршуються показники прижиттєвої продуктивності та тривалості господарського використання в порівнянні 3 аналогічними у їх матерів. Тривалість життя матерів у середньому дорівнювала $3471 \pm 196$ днів, а дочок - на $6 \%$ менша (3281 \pm 191$)$. Подібна тенденція характерна середній тривалості господарського використання, яка у матерів становила $2541 \pm 199$ дні, а у дочок

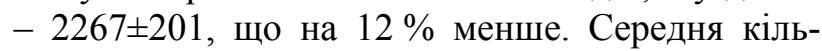
кість лактацій у матерів становила $6,6 \pm 0,5$, а у дочок $-5,5 \pm 0,5$. Відповідно, середня тривалість

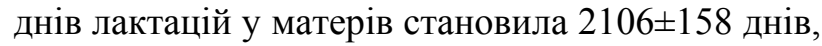

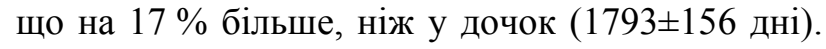
Величина середнього довічного надою у дочок становить $88 \%$ від надою матерів (25803 \pm 2189 кг). Відповідно, середній надій на один день життя у матерів становив $6,8 \pm 0,3$ кг, а у дочок $-6,3 \pm 0,3$ кг. На один день лактування, відповідно, $12,7 \pm 0,4$ кг та $12,4 \pm 0,4$ кг.
Середній коефіцієнт господарського використання матерів був на $6 \%$ вище, ніж у дочок $(63 \pm 2,4)$, середній коефіцієнт лактування матерів переважав на $6 \%$ середній коефіцієнт лактування дочок $(79,0 \pm 1,2)$; середній коефіцієнт продуктивного використання матерів $(56,7 \pm 1,9)$ був вищим на $12 \%$ у порівнянні 3 дочками.

Інтенсивність селекції стада за показниками довічного використання залежить від ступеня успадковуваності ознак, а ті, у свою чергу, - від значної кількості генотипових i паратипових чинників.

Значення коефіцієнтів успадковуваності («дочки - матері») показників довічного використання корів української бурої молочної породи низькі та в більшості випадків статистично недостовірні. Успадковуваність тривалості життя корів $\epsilon$ низькою $\mathrm{h}^{2}=0,09$; тривалості господарського використання $-\mathrm{h}^{2}=0,12$; тривалості лактаційного періоду $-\mathrm{h}^{2}=0,08$. Ще нижчими значеннями коефіцієнта успадковуваності характеризуються величина довічного надою $\mathrm{h}^{2}=0,07$; надій на 1 день життя $\mathrm{h}^{2}=0,02$. Величини коефіцієнтів успадковуваності дають підстави стверджувати про недоцільність ефективного масового добору корів за ознаками довічного використання матерів. Для підвищення довічної продуктивності корів відбір лише за методом «мати - дочка» не матиме бажаного селекційного ефекту.

Величини показників успадковуваності ознак довічного використання корів, визначених методом дисперсійного аналізу через силу впливу «батько - дочка», виявились вищими 3 різними ступенями достовірності порівняно 3 коефіцієнтами успадковуваності, одержаними від обчислення методом «мати - дочка».

Так, сила впливу батька як фактора, що обумовлює показники довічного використання його дочок, становлять $\left(\eta_{\mathrm{x}}^{2}\right)$ : днів життя $-30,7 \%$; вік господарського використання - 33,4 \%; кількість лактацій - 28,1 \%; кількість днів лактації 30,2 \%; довічний надій - 25,7 \%; надій на 1 день життя $20,5 \%$; надій на 1 день лактування - 31,6\%; КГВ - 30,1\%; КЛ - 27,6 \%; КПВ - 31,7.

Сила впливу лінійної належності корів як фактор, що обумовлює показники довічного використання його дочок, була дещо нижчою, і становила $\left(\eta^{2}\right)$ : днів життя - $11,5 \%$; вік господарського використання - 11,5 \%; кількість лактацій $10,9 \%$; кількість днів лактації - 9,7 \%; довічний надій $-9,7 \%$; надій на 1 день життя - 10,5\%; надій на 1 день лактування - 19,9 (Р<0,05)\%; КГВ - 7,5 \%; КЛ - 6,8\%; КПВ - 4,2.

Висновок. У результаті проведених досліджень встановлено, що коефіцієнти успадкуван- 
ня («дочки - матері») показників довічного використання корів мають низькі значення - в межах 0,02-0,12. Сила впливу батька як фактора, що обумовлює показники довічного використання його дочок, $\left(\eta^{2}\right)$ знаходиться в межах 20,5-33,4\%.

Встановлені в ході досліджень величини коефіцієнтів успадкування та сили впливу на показ-

\section{БІБЛІОГРАФІЯ}

1. Бабік Н. П., Федорович С. I., Федорович B. В. Тривалість та ефективність довічного використання корів молочних порід залежно від країни походження їх батька // Розведення і генетика тварин. - 2017, №54. - С. 19-29.

2. Бабік Н. П. Вплив генотипових чинників на тривалість і ефективність довічного використання корів голштинської породи // Розведення і генетика тварин. - 2017, №53. - С. 61-69.

3. Комп'ютерні методи в сільському господарстві та біології / О. М. Царенко, Ю. А. Злобін, В. Г. Скляр, С. М. Панченко. - Суми : Університетська книга, 2000. - 200 с.

4. Полупан Ю. П. Ефективність довічного використання корів різних країн селекції // Вісник Сумського НАУ. - 2014. - Вип. 2/2(25), серія «Тваринництво». - С. 14-20.

5. Безрутченко I. М. Ефективність довічного використання корів української червоної молочної породи : матеріали XII наукової конференції молодих вчених та аспірантів; ІРГТ НААН. Чубинське, 2014. - С. 15-17.

\section{ANNOTATION}

Skliarenko Yu. I. The effectiveness of lifetime use of cows depending on genotypic factors.

The article presents the main results of research on determining the influence of genotype factors on indicators of lifetime use of cows. Domestic scientists pay much attention to the study of the influence of genotype factors on indicators of lifetime use of cows. The study was conducted according to the materials of the primary breeding records in the herd of State Enterprise «Experimental Farm of Institute of Agriculture of Northern East of NAAS» of Sumy region - it is one of the leading breeding factories of Ukrainian brown dairy breed cattle breeding. The materials of the electronic information database in SUMS ORSEC format are used as of 2017. In result of the conducted researches we have found that in animals of Ukrainian brown dairy breed worse indicators of lifetime productivity and duration of economic use. The coefficients of inheritance («daughter-mother») of indica- ники довічного використання корів за методом «батько - дочка» в умовах великомасштабної селекції молочної худоби дають підстави очікувати вищої ефективності підбору з інтенсивним використанням бугаїв-поліпшувачів за ознаками довічного використання корів у порівнянні з методом «мати - дочка».

6. Боровиков B. STATISTICA: искусство анализа данных на компьютере. Для профессионалов. - СПб : Питер, 2001. - 656 с.

7. Братушка Р. В. Влияние возраста первого отёла на эффективность хозяйственного использования коров украинской чёрно-пёстрой молочной породы // Розведення і генетика тварин. К. : Аграрна наука, 2013. - Вип. 47. - С. 119-125.

8. Милостевый Р. В., Карлова Л. В. Продуктивное долголетие голштинских коров европейской селекции разных линий в условиях промышленной технологии // Розведення і генетика тварин. - 2017, №54. - С. 61-69.

9. Хмельничий Л. М., Вечорка В. В. Продуктивне довголіття дочок бугаїв-плідників української чорно-рябої молочної породи // Розведення і генетика тварин. - 2016, №52. - С. 134-143.

10. Хмельничий Л. М., Вечорка В. В. Особливості спадкового впливу умовної кровності голштинської породи на показники довголіття корів української червоно-рябої молочної породи // Розведення і генетика тварин. - 2016, №51. С. $170-177$.

tors of lifetime use of Ukrainian brown dairy breed cows are low and in most cases statistically unreliable. Inheritance of life expectancy of cows is low $\mathrm{h}^{2}=0,09$; duration of economic use $-\mathrm{h}^{2}=0,12$; the duration of the lactation period $-\mathrm{h}^{2}=0.08$. Even lower the value of the coefficient of inheritance is characterized by the value of lifetime milk yield $\mathrm{h}^{2}=0,07$; milk yield per 1 day of life $\mathrm{h}^{2}=0,02$. We established in the course of studies coefficients of inheritance and the power of influence on the indicators of lifetime use of cows by the method of «father-daughter» in the context of large-scale breeding of dairy cattle give reason to expect high efficiency of selection with intensive use of bulls- producers on the grounds of lifetime use of cows in comparison with the method of «mother-daughter». The impact of origin for the father on the indicators of lifetime use is $20.5-33.4 \%$.

Key words: bull-producer, family, lifetime productivity, coefficient, lactation, milk yield. 